\title{
Youth participation in civil society and political life in Jharkhand
}

International Institute for Population Sciences (IIPS)

Population Council

Follow this and additional works at: https://knowledgecommons.popcouncil.org/departments_sbsr-pgy

Part of the Demography, Population, and Ecology Commons, Family, Life Course, and Society Commons, International Public Health Commons, and the Medicine and Health Commons How does access to this work benefit you? Let us know!

\section{Recommended Citation}

International Institute for Population Sciences (IIPS) and Population Council. 2009. "Youth participation in civil society and political life in Jharkhand," Youth in India: Situation and Needs Policy Brief no. 7. Mumbai: IIPS. 


\section{Youth participation in civil society and political life in Jharkhand}

Youth participation in civil society and political life is increasingly recognised as an important development objective. The opportunities for participation that young people experience in their communities may influence their development and the kind of transitions they make to adulthood. For example, evidence that comes largely from developed countries indicates that youth who participate in community activities or are connected to their communities are less likely than others to engage in risktaking behaviours. Moreover, behaviours and attitudes relating to community participation that individuals adopt as young people predict their lifelong civic affiliations and perspectives. $^{a}$

In India, the National Youth Policy 2003 has underscored the role of India's youth in political decision-making, and has argued for greater representation of youth in appropriate bodies as well as more extensive youth participation in the design and implementation of programmes. ${ }^{b}$ Indeed, there is a recognition that today's youth, who have better access to skills and information than those of earlier generations, can play an important role in influencing political processes and the socio-economic development of the country. However, there is very little evidence of the extent to which Indian youth participate in civil society and political life.

This policy brief documents the participation of youth in Jharkhand in civil society, the extent to which they uphold secular attitudes and their perceptions about and participation in political processes.
The study

Data are drawn from the Youth in India: Situation and Needs study, a sub-nationally representative study undertaken for the first time in India of key transitions experienced by young people in six states of India, including Jharkhand. The study included a representative survey of young people in both rural and urban settings. Respondents included unmarried women and men and married women aged 15-24 and, in view of the paucity of married men in these ages, married men aged 15-29.

The survey was conducted in Jharkhand in 2006. A total of 8,814 married and unmarried young women and men were interviewed. Of these, 2,684 were married young women, 2,730 unmarried young women, 1,259 married young men and 2,141 unmarried young men. This brief is based on data obtained from 2,637 young men and 5,414 women aged $15-24$.

To what extent do young people participate in civil society?

Participation in civil society, as measured by participation in community-led activities and membership in an organised group, was limited among youth, particularly among young women. Specifically, $31 \%$ of young men compared to $5 \%$ of young women reported that they had participated in any communityled programmes such as cleanliness drives, health promotion activities, and celebration of festivals and national days. Likewise, just $9 \%$ of young men and $4 \%$ of young women reported membership in organised groups such as self-help groups, and sports and social clubs. In total, $35 \%$ of young men and $8 \%$ of young women reported participation in civil society.

\footnotetext{
a National Research Council and Institute of Medicine. 2005. Growing up Global: The Changing Transitions to Adulthood in Developing Countries, Washington, D.C.: The National Academies Press.

b Ministry of Youth Affairs and Sports. 2003. National Youth Policy 2003, New Delhi: Government of India.
} 


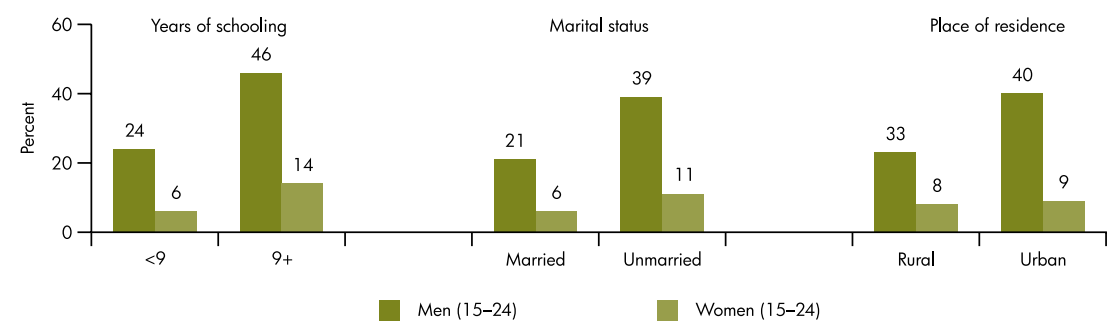

Findings indicate that participation in civil society was more likely to be reported by better than less educated youth, and differences were particularly wide among young men. For example, $24 \%$ of young men with less than 9 years of schooling participated in civil society compared to $46 \%$ of those with at least 9 years of schooling. The corresponding percentages among young women were 6 and 14 .

Findings also show that more unmarried than married youth reported participation in civil society. Two-fifths of unmarried young men compared to one-fifth of married reported such participation. Among young women, $11 \%$ of the unmarried compared to $6 \%$ of the married had participated in civil society.

Finally, findings also show that rural-urban differences in civil society participation were narrow among young men-two-fifths of young men in urban areas and one-third of those in rural areas reported participation in civil society. Among young women the difference was not apparent (9\% and $8 \%$, respectively).

Do young people uphold secular attitudes? In order to gauge the extent to which youth uphold secular attitudes, two issues were addressed. The first assessed young people's attitude to social interaction with individuals of different castes and religions. Specifically, youth were asked whether they would mix freely and eat together with a person from a different caste or religion, and would talk to someone who had an inter-caste marriage. The second issue assessed young people's tolerance towards someone who showed disrespect to their religion. Specifically, youth were asked whether or not they considered it acceptable to punish someone who showed disrespect to their religion.

Percentage of youth expressing secular attitudes about social interaction

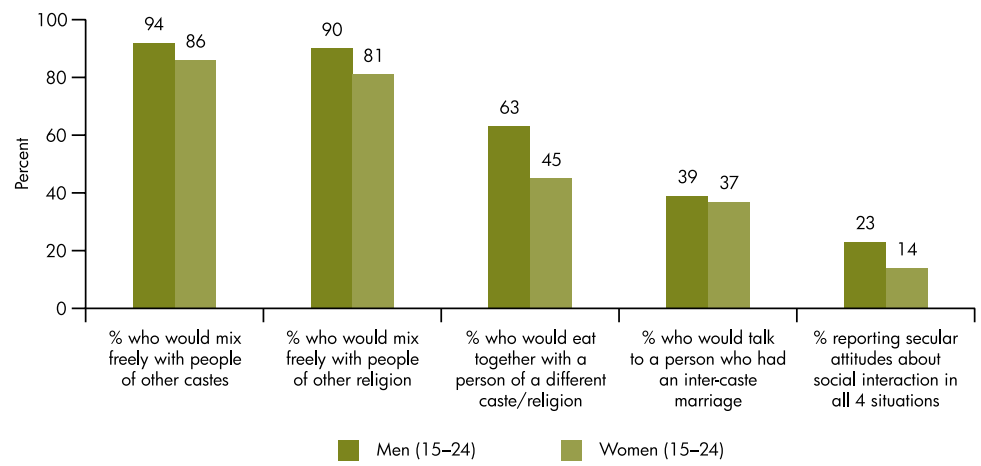


Percentage of youth expressing secular attitudes, according to selected characteristics

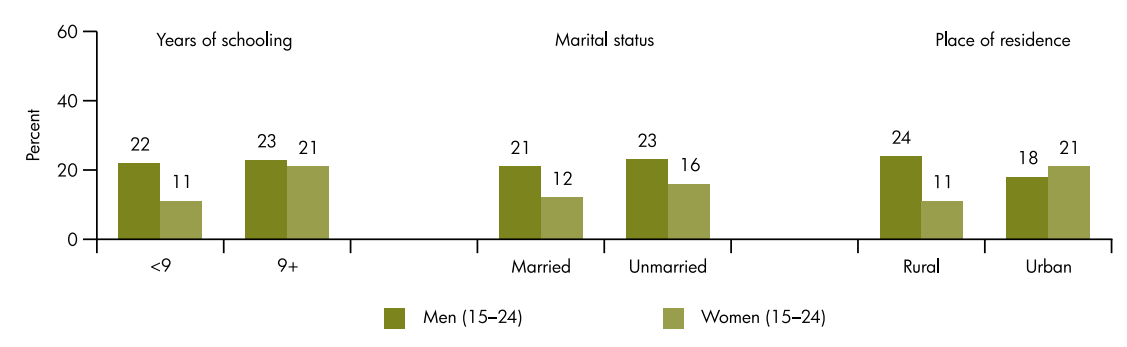

Findings show that almost all young men $(90-94 \%)$ and fewer young women (81-86\%) expressed secular attitudes about mixing freely with individuals of different castes and religions. However, considerably fewer-63\% of young men and $45 \%$ of young womenreported that they would eat together with a person from a different caste or religion; and even fewer- $37-39 \%$ of young men and women reported that they would talk to someone who had an inter-caste marriage.

Few youth reported affirmatively to all four items-just 23\% of young men and $14 \%$ of young women. Among young women, the better educated were more likely than the less educated to report so; $21 \%$ of young women with at least 9 years of schooling compared to $11 \%$ of those with less than 9 years of schooling reported secular attitudes in all four situations. Likewise, secular attitudes in all four situations were more likely to be reported by unmarried compared to married young women ( $16 \%$ and $12 \%$, respectively) and those in urban compared to rural areas $(21 \%$ and $11 \%)$. Among young men, differences by education and marital status were not observed; however, young men in rural areas were somewhat more likely than those in urban areas to express secular attitudes in all four situations ( $24 \%$ and $18 \%$, respectively).

In addition, fewer than one in three young men $(29 \%)$ and just two in five young women (40\%) considered it unacceptable to retaliate, through punitive action, against someone who showed disrespect to their religion.

What do young people think about the commitment of political parties and fairness of the electoral process?

Considerable proportions of youth reported disillusionment with the commitment of political parties to work for change at the community level. Indeed, $63 \%$ of young men and $41 \%$ of young women believed that improvement in their village (rural youth) or neighbourhood (urban youth) was unlikely, no matter which political party governed the state. Another 7\% and 17\%, respectively, reported that they had no opinion about the commitment of political parties.

It is notable, however, that the majority of youth $-76 \%$ of young men and $73 \%$ of young women-perceived that the electoral process

Percentage of youth aged 20 and above who voted in the last election preceding the interview, according to selected characteristics

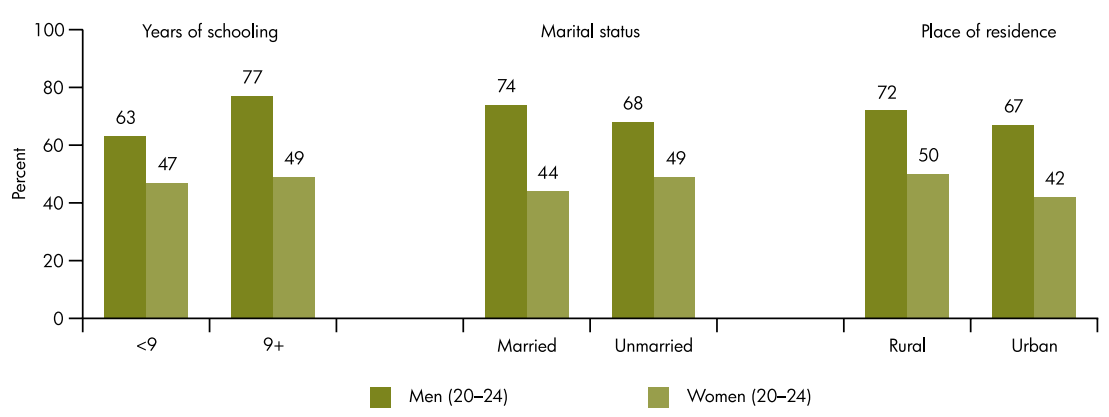


was fair and one could vote without fear or pressure. Even so, almost one in five young men and one in seven young women felt that one could not vote freely.

Do young people exercise their voting rights?

Findings suggest that more young men than women exercise their voting rights. Of those who were eligible to vote in the last election preceding the interview (aged 20 years and above at the time of the interview), $70 \%$ of young men and just $48 \%$ of young women had cast their vote. Rural youth were more likely to have voted in the last election than their urban counterparts. Better educated young men were more likely to have voted than those with less than 9 years of education, but differences were negligible among young women. Marital status differences suggest that while married young men were more likely than unmarried young men to have voted in the last election, among young women, it was the unmarried who were more likely to have voted.

\section{Programme recommendations}

Findings call for actions to promote youth participation, particularly the participation of young women, in civil society and political life.

\section{Promote youth participation in civil society}

Findings that opportunities to engage in civil society remain limited for many youth call for programmes at the school, college and community levels-through national service programmes, sports and other non-formal mechanisms that encourage civic participation. Special attention must be paid to developing community-level programmes for young women, large proportions of whom are out of school.

\section{Build secular attitudes}

Evidence suggests that youth in Jharkhand did not uniformly express secular attitudes. This finding underscores the need to encourage the development of secular attitudes from a young age, incorporate value building components that reinforce secular attitudes and stress peaceful resolution of conflict in the school curriculum as well as in programmes directed at young people more generally.

\section{Address young people's disillusionment with the commitment of political parties}

Findings suggest that a large majority of youth are disillusioned with the commitment of political parties to work for change at the community level. The political system in the state needs to make special efforts to address the concerns of youth and encourage youth participation in the political processes in more meaningful ways.

\section{Encourage young women to exercise their voting rights}

More young men than women exercised their right to vote, highlighting the need to focus on encouraging young women to vote. Special efforts must be made to identify and address the obstacles that young women face in exercising their right to vote. 